UDC 621.313.13.1

Doi: $10.31772 / 2587-6066-2019-20-2-284-290$

For citation: Shvaleva N. A., Fadeev A. A., Eresko T. T. [Mathematical model of a linear electrodynamic engine operation on impact with account for elastic deformation of the hardened surface]. Siberian Journal of Science and Technology. 2019, Vol. 20, No. 2, P. 284-290. Doi: 10.31772/2587-6066-2019-20-2-284-290

Для цитирования: Швалева Н. А., Фадеев А. А., Ереско Т. Т. Математическая модель работы линейного электродинамического двигателя при ударе с учетом упругой деформации упрочняемой поверхности // Сибирский журнал науки и технологий. 2019. Т. 20, № 2. C. 284-290. Doi: 10.31772/2587-6066-2019-20-2-284-290

\title{
MATHEMATICAL MODEL OF A LINEAR ELECTRODYNAMIC ENGINE OPERATION ON IMPACT WITH ACCOUNT FOR ELASTIC DEFORMATION OF THE HARDENED SURFACE
}

\author{
N. A. Shvaleva*, A. A. Fadeev, T. T. Eresko \\ Reshetnev Siberian State University of Science and Technology \\ 31, Krasnoyarsky Rabochy Av., Krasnoyarsk, 660037, Russian Federation \\ * E-mail: natalyashvaleva@ya.ru
}

Operational characteristics of contacting elements of cars and mechanisms are by far defined by a layer quality indicators at the surfaces of contact. One of the ways of increasing details durability, including missile and space equipment details, is the superficial plastic deformation (SPD). In the article aspects of dynamic ways of hardening from the position of the wave theory of blow are considered.

The construction of a shock stand on the basis of a linear electrodynamic drive with a size of $60 \mathrm{~mm}$, operating in a shock-pulse mode, as well as a well-known mathematical model of the workflow - the movement of the armature with the tool at the moment of striking the surface. This model does not fully describe the operation process since the mass of the striker taken into account equaled $1 \mathrm{~kg}$, which does not characterize the process of the impact tool, the purpose of which is the object deformation (for example, work hardening with the aim of surface material sealing or breakdown of the hole in it, or applying license plates markers).

The mathematical model that describes the movement of the armature with the tool, taking into account the elastic deformation of the hardened surface was obtained. In the course of the performed calculation, the magnitude of the elastic deformation of the hardened surface was calculated from the dynamic component of the force impulse applied to it through the indenter (the tip of the impact tool).

The layout of the shock stand with the equipment used, are offered. Experiments on the signal recording with various arrangements of piezoelectric transducers on the anvil - the hardened surface (diagrams of the sensors location are given) were carried out.

Keywords: blow, mathematical model, elastic deformation, contact spot, linear electrodynamic engine, counterbody, indenter.

\section{МАТЕМАТИЧЕСКАЯ МОДЕЛЬ РАБОТЫ ЛИНЕЙНОГО ЭЛЕКТРОДИНАМИЧЕСКОГО ДВИГАТЕЛЯ ПРИ УДАРЕ С УЧЕТОМ УПРУГОЙ ДЕФОРМАЦИИ УПРОЧНЯЕМОЙ ПОВЕРХНОСТИ}

\author{
Н. А. Швалева ${ }^{*}$ А. А. Фадеев, Т. Т. Ереско \\ Сибирский государственный университет науки и технологий имени академика М. Ф. Решетнева \\ Российская Федерация, 660037, г. Красноярск, просп. им. газ. «Красноярский рабочий», 31 \\ * E-mail: natalyashvaleva@ya.ru
}

\begin{abstract}
Эксплуатационные характеристики контактирующих элементов машин и механизмов в значительной степени определяются показателями качества слоя у поверхностей контакта. Одним из способов повышения прочности деталей, в том числе деталей ракетно-космической техники, является поверхностное пластическое деформирование (ППД). В статье рассмотрены аспекты динамических способов упрочнения с позиции волновой теории удара.

Представлена конструкция ударного стенда на базе линейного электродинамического привода с типоразмером 60 мм, работающего в ударно-импульсном режиме, а также известная математическая модель рабочего проиесса - движения якоря с инструментом в момент удара бойка о поверхность. Данная модель в полной мере не описывает процесс работы, так как масса бойка учитывалась равной 1 кг, что не характеризует процесс работы ударного инструмента, ичелью которого является деформация объекта (например, наклеп с целью поверхностного уплотнения материала или пробой отверстия в нем, или нанесение номерных маркеров).
\end{abstract}


Получена математическая модель, которая описывает движение якоря с инструментом с учетом упругой деформации упрочняемой поверхности. В ходе выполненного расчета вычислена величина упругой деформации упрочняемой поверхности по динамической составляющей силового импульса, прикладываемого к нему через индентор (наконечник ударного инструмента).

Представлена схема ударного стенда, используемое оборудование. Были проведень эксперименты по регистрации сигнала с различным расположением пьезодатчиков на наковальне - упрочняемой поверхности (схемы расположения датчиков приведены). Выполнено сравнение расчетных данных по показаниям осциллографа с теоретическими данными математической модели, где выявлено расхождение и объяснены возможные факторы его возникновения. Несмотря на расхождения и недостатки, расчеты и проведенный опыт указывают на наличие упругой деформации, а значит, ударная установка может найти применение при обработке поверхностно - пластическим деформированием ударными способами рабочих поверхностей деталей, в том числе деталей ракетно-космической техники.

Ключевые слова: удар, математическая модель, упругая деформация, пятно контакта, линейный электродинамический двигатель, контр-тело, индентор.

Introduction. Currently in order to increase durability of car details, including missile and space equipment details, dynamic ways of superficial plastic deformation (SPD) are widely applied with shock deformation impact on the processed surface in conditions of faltering contact, ensuring the most effective way of enhancing operational properties of car details, improving fatigue durability and hardness of a detail surface under the influence of impact load [1]. Stamping is one of the examples of dynamic SPD.

It is known that one of the main characteristics of dynamic loading efficiency under SPD is the share of energy of blow used for elasto-plastic deformation of the processed material in a deformation zone. According to the wave theory the blow is considered as a form of flat acoustic waves extending on the collided bodies and having the period, amplitude and duration. The period of such a wave is called a shock impulse, the form of which represents the change of amplitude in time. The form of an impulse defines efficiency of dynamic loading [2].

Therefore, in the research of bodies' interaction, dynamic contact tasks including those connected with shock impact are the most interesting and challenging. For a more detailed description of shock interaction nature (especially relevant in engineering practice) the rheological model needs to solve not only contact problems, but also to consider the wave phenomena [3; 4].

In mechanical engineering for SPD implementation via dynamic methods devices with mechanical or pneumatic drive have found broad application. Also, linear electric drives of shock action due to high specific energy of blow and speed have been widely adopted $[5 ; 6]$. For example, for stamping and sealing devices [7;8] have been used.

Construction of a shock stand on the basis of a linear electrodynamic drive. The design of the shock stand on the basis of the linear electrodynamic drive (LEDD) operating in the shock - pulse mode is known to have been developed by the SIBGAU team [9]. The design and the analytical model of the electrodynamic engine is given in the work [10]. For this stand there is an equation describing the movement of the armature with the tool at the moment of striking the surface [11] developed on the basis of a process functioning algorithm [12] and a design technique of a linear engine [13].
Description of mathematical model of shock process. The equation describing the movement of an armature with the tool taking into account elastic deformation of material [14] is known. In this equation weight of the striker $m_{b}$ equaled $1 \mathrm{~kg}$. For further calculations for mathematical model of shock process and pilot study to compare the size of elastic deformation of the hardened surface, received as a result of mathematical modeling and during the experiment, it is required to specify the striker weight and parameters of shock process. In the right member of equation the first member characterizes the total dynamic effort arising under speed change of an armature with the tool. The second member of the equation characterizes the static effort developed by an armature engine winding. The third member of the equation is defined by the size of required elastic deformation $\left(\alpha_{y-n}\right)$ of the processed material and properties of materials couple $(k)$ "striker - surface" [15].

The research objective is to determine technical specifications of LEDD with a standard size $60 \mathrm{~mm}$ (marking 2L60L) and also to determine the extent of elastic deformation of the hardened surface by means of the obtained mathematical model of the impact device operation, and to further compare the rated value of elastic deformation of the hardened surface with the results of the pilot study.

For the description of shock impulse formation, generated in the system: striker - the processed surface in the deformation center, we will enter the following marking: $P_{u}$ - amplitude impulse stage passing to the processed metal, $\mathrm{H} ; a_{1.2}$ - the speed of shock wave distribution in the striker and a wave guide respectively, $\mathrm{m} / \mathrm{s}$; $\rho_{1.2}-$ material density respectively the strike and a wave guide, $\mathrm{kg} / \mathrm{m}^{3} ; E_{1.2}$ - the elasticity module of material respectively the striker and the wave guide, $\mathrm{Pa} ; F_{1.2}-$ striker and a wave guide cross-sectional area, in this case we accept equal values; $k$ - resistance factor to introduction.

Let's assume that the shock impulse of irregular shape $P_{u}$, having reached the processed surface, is distributed on the passing $P_{k}$ and the reflected $P_{o}$ approaches the deformation zone via the tool (striker). The passing impulse forms a dynamic component of the deformation force [15].

$$
P_{u}=P_{k}+P_{o},
$$

where

$$
P_{k}=P_{u}(1+\psi) ; P_{o}=P_{u} \psi ; P_{u}=q \frac{C_{1} v}{2},
$$


where $C_{1}-$ striker acoustic rigidity; $C_{2}$ - wave guide acoustic rigidity, their relation is determined by formulas:

$$
r=C_{1} / C_{2} ; \quad C_{1,2}=\rho_{1,2} \cdot a_{1,2} \cdot F_{1,2} .
$$

For loading of metals when hardening SPD it is required to consider interaction of the deformation wave with the border under which material properties and the specified radius of curvature are considered by resistance factor to introduction of $k=(2.4 \ldots 7.5) 10^{8} \mathrm{H} / \mathrm{m}$. Coefficients of reflection and deformation wave passing to the loaded surface are defined:

$$
\psi=1-2 \Delta ; \quad \Delta=\exp (-b a t)
$$

where $b=k /\left(E_{1} / F_{1}\right)$.

At various acoustic striker and a wave guide hardness, through their contacting border a part of energy from the deformation wave passes. The wave reflected from the border possesses the other left energy. Change of force in the deformation wave as it passes through the border of arms' zones can be characterized by passing and reflection factors.

Expression for determination of passing the $q$ factor, a direct wave of deformation is written as:

$$
q=\frac{2}{1+r}
$$

In relation to this case, strikers and a wave guide have the identical cross-sectional area and material, therefore, $\rho_{1}=\rho_{2} ; a_{1}=a_{2} ; r=F_{1} / F_{2}$.

In the work [16] the dependences confirmed experimentally for calculation of deformation of the hardened material are established. The dependence for elastic deformation is written as:

$$
\alpha_{y}=\frac{\alpha_{o}}{\sqrt[3]{1+\frac{2 h}{\alpha_{y}}}},
$$

where $h$ - residual approximation which is equal to the depth of the reconstructed print, $\mathrm{m} ; \alpha_{y}$ - elastic approximation disappearing with the removal of loading caused by elastic reconstruction of the indentor and counterbody, $\mathrm{m} ; \alpha_{o}$ - approximation of the tool to the loaded surface at purely elastic power contact (the Hertz formula), $\mathrm{m}$.

These values are found by formulas:

$$
\begin{gathered}
h=\frac{P_{u}}{2 \pi R_{p r} H D n_{D}} ; \\
\alpha_{o}=\sqrt[3]{\frac{9 \pi^{2}}{16} \cdot \frac{\left(k_{i}+k_{m}\right)^{2} P^{2}}{R_{p r}}} ; \\
\alpha_{y}=\frac{\alpha_{o}}{\sqrt[3]{1+2 h / \alpha_{y}}},
\end{gathered}
$$

where $R_{p r}$ - is the specified curvature radius, in relation to this case - infinitely big, m; $H D$ - the plastic hardness of the processed metal, $\mathrm{MPa} ; n_{D}-$ dynamic coefficient of plastic hardness where

$$
n_{D}=0.5\left(1-137 \frac{v}{H D}+\sqrt{1+2250 \frac{v}{H D}}\right)
$$

$v$ - striker's speed, $\mathrm{m} / \mathrm{s} ; k_{i} k_{m}$ - elastic constants of the respective indentor and processed metal, $1 / \mathrm{MPa}$.

$$
k_{i}=\frac{1-\mu_{i}^{2}}{\pi E_{i}}, k_{m}=\frac{1-\mu_{m}^{2}}{\pi E_{m}},
$$

where $E_{i}, E_{m}$ - elasticity module according to indenter and the processed metal, MPa, $\mu_{i}, \mu_{m}$ - Poisson's ratio according to the indenter and the processed metal.

Results of mathematical modeling. During the transformation process the mathematical model (1) which describes operation of the stand based on the linear electrodynamic drive of a standard size $60 \mathrm{~mm}$ (mark 2L60L) with regard to elastic deformation of the hardened surface was received.

$$
\begin{aligned}
\frac{d^{2} x_{b}}{d t^{2}} & =\left(\frac{z^{2} B_{z}^{2}}{m_{b} R_{y a . A}}-\frac{k_{D}}{m_{b}}\right) \cdot \frac{d x}{d t} \cdot\left(1-e^{-\frac{t}{T_{m}}}\right)+ \\
& +\frac{z B_{z} I_{y a}}{m_{b}}-\left(k \cdot \frac{\alpha_{o}}{\sqrt[3]{1+\frac{2 h}{\alpha_{y}}}}\right) / m_{b},
\end{aligned}
$$

where $x_{b}-$ striker removal, $\mathrm{m} ; m_{b}-$ striker mass, $\mathrm{kg}$; $z$ - anchor design parameter; $B_{z}$ - magnetic induction in the clearance gap, T; $R_{y a \cdot A}-$ active resistance of the anchor coil, Ohm; $k_{D}$ - damping factor, $\mathrm{H} \cdot \mathrm{s} / \mathrm{m} ; t$ - dispersal time, $\mathrm{s} ; T_{m}$ - dispersal time constant, $\mathrm{s} ; \mathrm{I}_{y a}-$ current in the anchor winding, A; $k$ - resistance factor to striker introduction, $\mathrm{H} / \mathrm{m} ; \alpha_{0}-$ approximation of the tool with the loaded surface at purely elastic power contact, $\mathrm{m}$.

In the process of calculation the size of elastic dynamic deformation amounted to $5.158 \cdot 10^{-9}$. Provided that the tool speed (striker) (according to data sheet) $v=4.5 \mathrm{~m} / \mathrm{s}$; full amplitude of shock impulse $-\mathrm{P}_{u}=13.5 \mathrm{H}$; residual approximation $h=4.892 \cdot 10^{-13} \mathrm{~m}$; approximation of the tool and the loaded surface at purely elastic power contact $\alpha_{\mathrm{o}}=7.291 \cdot 10^{-7} \mathrm{~m}$; material of the processed surface - steel 45, striker material - quenched steel 40X.

A specified mathematical model allows to estimate characteristics of linear electrodynamic engine with a standard size of $60 \mathrm{~mm}$ operating in shock-pulse mode at the time when the striker hits the hardened surface and also to determine the size of elastic deformation of the hardened surface.

Experiment procedure. The stand is designed on the basis of the linear electrodynamic drive (fig. 1).

The stand consists of the following elements: linear electric motor 1 with a percussion instrument (striker) 3 fixed on the bed with an anvil 4 (with the anvil rigidly fixed on support 6). Piezoelectric sensors 5 are fixed onto the anvil (hardened surface). Signals from the sensors arrive at the recording device 7 (oscillograph and/or personal computer). The linear engine power is supplied by power supply 2 .

The stand operation: when supplying back feed from the power supply 2 to linear electric motor 1 (the reverse mode) the anchor ejects with the tool (striker) 3 from the inductor's clearance gap and impacts the anvil 4, equipped with piezoelectric sensors 5, signal from which is recorded with oscillograph 7. 
Measurement of elastic deformation is done by means of: piezoelectric sensors, ADS-2071MV oscillograph, oscillographic probe.

Experiments on signal recording with various arrangements of piezoelectric sensor on the anvil (counterbody) were made.

Signal recording was done with oscillograph, the signal was transmitted via the probe with attenuation factor $1: 10$.

Sensor layouts are shown in fig. 2. On diagram No. 1 sensors are located on the outer side of the anvil, with sensor No. 1 opposite the working aperture. On diagram No. 2 sensor No. 1 is located inside, with sensor No. 2 on outer side. Oscillograms of impacts are shown in fig. 3 and 4.

Comparison of experimental data with the results of mathematical modeling. The calculated values of the first peak according to oscillograph (fig. 3, 4) and mathematical model are given in the table.

Calculation of elastic deformation according to oscillograph was made with reference to an earlier developed method of transformation factor calculation [5] and the Hooke's law under plane stress condition.

Comparison of estimated data according to oscillograph and theoretical data of mathematical model showed $14 \%$ divergence at the most.

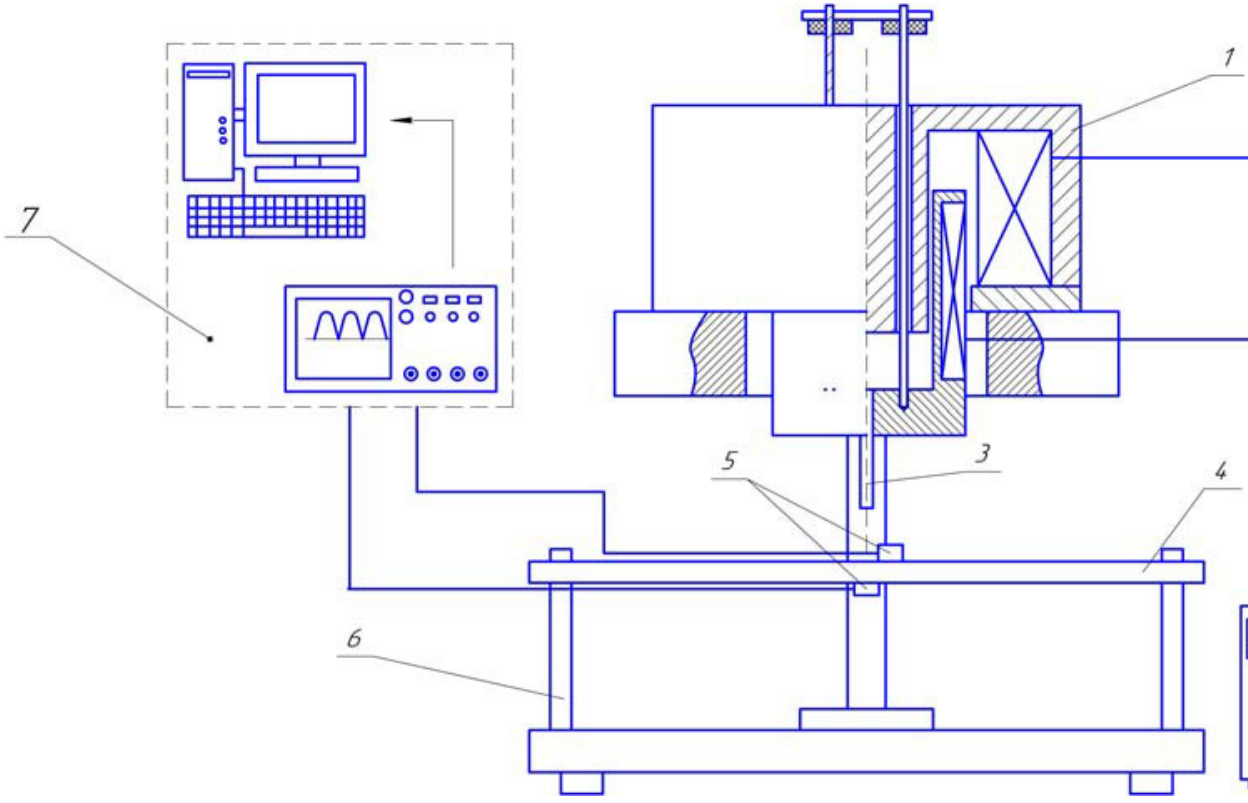

Fig. 1. The scheme of the shock stand

Рис. 1. Схема ударного стенда



$a$

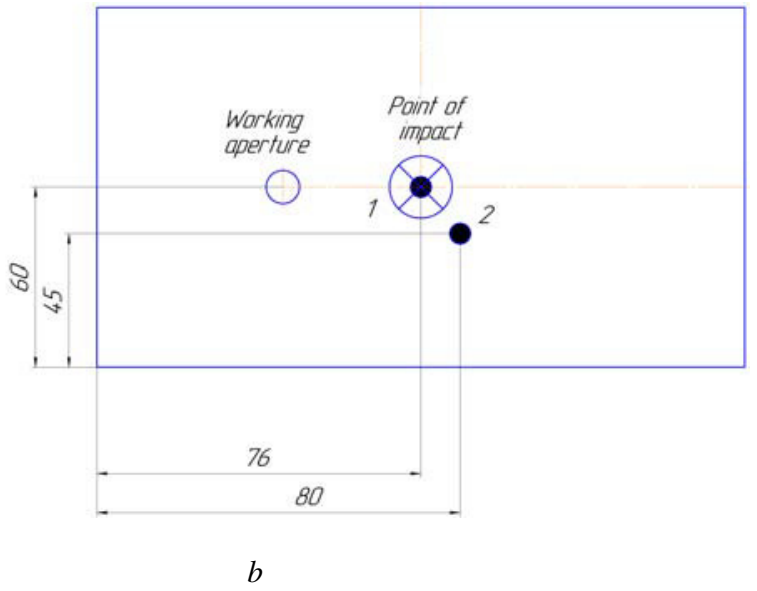

Fig. 2. Location of sensors:

$a$ - scheme № $1 ; b$ - scheme № 2

Рис. 2. Схема расположения датчиков:

$a$ - схема № $1 ; b$ - схема № 2 




Fig. 3. Recording of a signal from sensors according to the scheme № 1

Рис. 3. Регистрация сигнала датчиков по схеме № 1

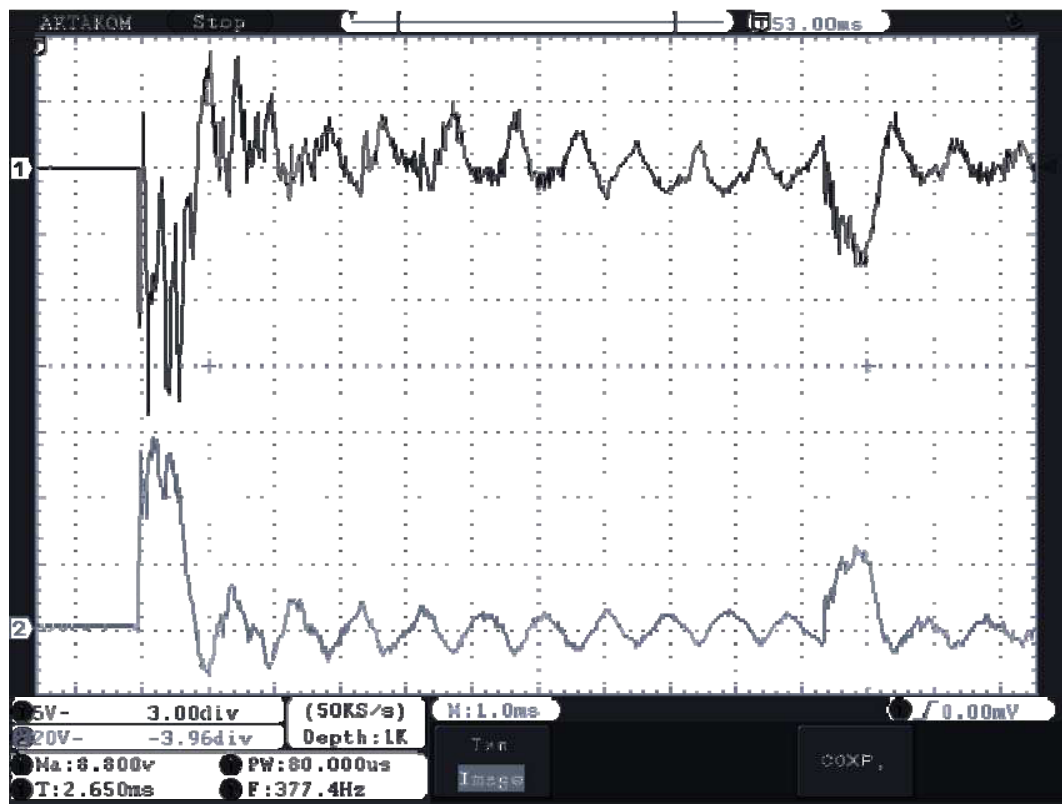

Fig. 4. Recording of a signal from sensors according to the scheme № 2

Рис. 4. Регистрация сигнала датчиков по схеме № 2

Comparative results of the experiment and mathematical modeling

\begin{tabular}{|c|c|c|c|c|c|c|}
\hline $\begin{array}{l}\text { dia- } \\
\text { gram }\end{array}$ & $\begin{array}{c}\text { No } \\
\text { In seq. }\end{array}$ & $\begin{array}{c}\text { First stress peak } \\
\text { value of sensor, B }\end{array}$ & $\begin{array}{l}\text { Length of the first } \\
\text { impulse, } \mathrm{ms}\end{array}$ & $\begin{array}{c}\text { Increment } \\
\text { velocity, } \mathrm{m} / \mathrm{s}\end{array}$ & $\begin{array}{l}\text { Estimated defor- } \\
\text { mation value, } \mathrm{m}\end{array}$ & $\begin{array}{l}\text { Experimental defor- } \\
\text { mation value, } \mathrm{m}\end{array}$ \\
\hline \multirow{2}{*}{$a$} & 1 & 215 & 0.01 & \multirow{4}{*}{3.3} & \multirow{4}{*}{$5.158 \cdot 10^{-9}$} & $4.418 \cdot 10^{-9}$ \\
\hline & 2 & 38 & 0.05 & & & $3.904 \cdot 10^{-9}$ \\
\hline \multirow{2}{*}{$b$} & 1 & 12 & 0.1 & & & $2.466 \cdot 10^{-9}$ \\
\hline & 2 & 55 & 0.03 & & & $3.39 \cdot 10^{-9}$ \\
\hline
\end{tabular}


Conclusion. While performing the works the mathematical model of the linear electrodynamic engine operation with regard to hardened surface, elastic deformation was developed, also the elastic deformation in a contact spot was calculated. Experiments on signal recording with various arrangements of piezoelectric sensor on a counterbody (anvil) were made. Comparison of estimated data according to oscillograph and theoretical data of mathematical model was made, with the divergence which can be explained by the following factors:

1. Anvil material inhomogeneity: possible defects of the anvil material, work hardening. Another reason is that no defectoscopy of an anvil was applied and an anvil has a long term useful life.

2. Influence from mechanical (elastic) waves, such as: reflection, diffraction. Due to an aperture sensor No. 1 according to the layout 1 is placed in front of it.

3. Recordings of higher harmonics spread in the material made by piezoelectric sensors.

4. Influence of indirect calculation errors on experimental (approximate) dependences.

Despite divergences and shortcomings, it is possible to confirm a rather exact description of elastic deformation formation process in shock - pulse impact of the indenter on the hardened surface. Specified mathematical model of the linear electrodynamic drive operation in the shock pulse mode allows to calculate parameters of material deformation with the set characteristics of a shock machine, and also to research materials' mechanical properties under various loading conditions.

\section{Reference}

1. Kirichek A. V, Solovyev D. L, Afonin A. N, Schubert A., Zaydler H. [Prospects of creating the multilevel surface layer by the deformation hardening] Izvestiya Yugo-Zapadnogo gosudarstvennogo universiteta. Seriya Tekhnika i tekhnologii. 2013, No. 4, P. 015-019 (in Russ.).

2. Kirichek A. V, Silantiev S. A. [Determination of the energy parameters of the shock mechanism used to harden the surface of plastic deformation]. Izvestiya YugoZapadnogo gosudarstvennogo universiteta. 2014, No. 1 (52), P. 105-111.

3. Zaletdinov A. V. Matematicheskoye modelirovaniye volnovykh protsessov $v$ tverdykh telakh posle udarnogo vozdeystviya. Kand. Diss. [Mathematical modeling of wave processes in solids after shock. Cand. Diss.]. Voronezh, 2014. $138 \mathrm{p}$.

4. Radchenko, A. V. Radchenko P. A. Udarnovolnovyye protsessy $i$ razrusheniye $v$ anizotropnykh materialakh $i$ konstruktsiyakh: monografiya [Shock-wave processes and destruction in anisotropic materials and structures: a monograph]. Tomsk, Izd-vo Tom. gos. arkhit.-stroit. un-ta Publ., 2015, 204 p.

5. Fadeev A. A., Chestakov I. Y., Eresko T. T. [Use of the linear electrodynamic actuator for the research of shock interaction of materials]. Vestnik SibSAU. 2016, Vol. 17, No. 4, P. 1077-1087 (In Russ.).

6. Kirichek A., Silant'ev S. A. Determination of the Energy Parameters of the Shock Mechanism Used to Harden the Surface by Plastic Deformation. Applied Mechanics and Materials. 2015, Vol. 756, P. 85-91.
7. Ugarov G. G., Neiman V. Yu. Elektromagnitnyy udarnyy instrument [Electromagnetic percussion instrument]. Patent PF, No. 2099175, 1997.

8. Ugarov G. G., Neiman V. Yu. Ustroystvo dlya kleymeniya yuvelirnykh izdeliy $i$ instrumenta [A device for stamping jewelry and tools]. Patent PF, No. 2065360, 1996.

9. Stryuk A. I., Bezyazykov S. A., Shestakov I. A., Shelkovsky O. L. Elektrodinamicheskiy molot [Electrodynamic hammer]. Patent PF, No. 2062167, 1996.

10. Chestakov I. Y., Stryuk A. I., Fadeev A. A. Lineynyye elektrodinamicheskiye dvigateli. Konstruirovaniye. Prakticheskoye ispol'zovaniye [Linear electrodynamic motors. Designing. Practical use]. Krasnoyarsk, SibGAU Publ., 2011, 148 p.

11. Fadeev A. A., Chestakov I. Y., Eresko T. T. [A mathematical model of the percussion device on the basis of the linear electrodynamic actuator]. Materialy XVIII Mezhdunar. nauch. konf. "Reshetnevskie chteniya" [Materials XVIII Intern. Scientific. Conf "Reshetnev reading"]. Krasnoyarsk, 2014, P. 315-316 (In Russ.).

12. Stryuk A. I., Bezyazykov S. A., Shestakov I. A., Shelkovsky O. L. Sposob upravleniya rabotoy elektrodinamicheskogo molota [The method of controlling the operation of an electrodynamic hammer]. Patent PF, No. 2062168, 1996.

13. Eresko S. P, Eresko T. T, Fadeev A. A Sovershenstvovaniye konstruktsiy i metodov proyektirovaniya vibroudarnykh mekhanizmov [Improvement of designs and methods of design of vibro-shock mechanisms]. Krasnoyarsk, 2017, 190 p.

14. Shvaleva N. A, Fadeev A. A., Eresko T. T. [Mathematical model of the operation of a linear electrodynamic motor upon impact with allowance for elastic deformation]. Materialy XXII Mezhdunar. nauch. konf. "Reshetnevskie chteniya” [Materials XVIII Intern. Scientific. Conf "Reshetnev reading"]. Krasnoyarsk, 2018, P. 515-516 (In Russ.).

15. Kirichek A. V., Solov'ev D. L. Lazutkin A. G. Teknologiya i obirudovanie statiko-impul'snoj obrabotki poverchnosti plasticheskim deformirovaniem: Biblioteka tekhnologa [Technology and equipment, staticpulse processing surface plastic deformation: a Library technologist]. Moscow, Mashinostroenie Publ., 2004, 228 p.

16. Drozd M. S., Matlin M. M., Sidyakin Yu. I. Inzhenernye raschety uprugo-plasticheskoy deformatsii [Engineering analysis of elastic-plastic deformation]. Moscow, Mashinostroenie Publ., 1986, 230 p.

\section{Библиографические ссылки}

1. Перспективы создания многоуровневого поверхностного слоя деформационным упрочнением / А. В. Киричек, Д. Л. Соловьев, А. Н. Афонин [и др.] // Известия Юго-Западного гос. ун-та. Серия «Техника и технологии». 2013. № 4. С. 015-019.

2. Киричек А. В., Силантьев С. А. Определение энергетических параметров ударных механизмов, используемых для упрочнения поверхностным пластическим деформированием // Известия Юго-Западного гос. ун-та. 2014. № 1 (52). С. 105-111.

3. Залетдинов А. В. Математическое моделирование волновых процессов в твердых телах после удар- 
ного воздействия : дис. ... канд. тех. наук : 05.13.18. Воронеж, 2014. 138 c.

4. Радченко А. В. Радченко П. А. Ударно-волновые процессы и разрушение в анизотропных материалах и конструкциях : монография. Томск : Изд-во Том. гос. архит.-строит. ун-та, 2015. 204 с.

5. Фадеев А. А., Шестаков И. Я., Ереско Т. Т. Использование линейного электродинамического привода для исследования ударного взаимодействия материалов // Вестник СибГАУ. 2016. Т. 17, № 4. C. $1077-1087$.

6. Kirichek A., Silant'ev S. A. Determination of the Energy Parameters of the Shock Mechanism Used to Harden the Surface by Plastic Deformation // Applied Mechanics and Materials. 2015. Vol. 756. P. 85-91.

7. Пат. 2099175 РФ, МПК В25D13/00. Электромагнитный ударный инструмент / Г. Г. Угаров, В. Ю. Нейман ; заявитель и патентообладатель Институт горного дела СО РАН ; заявл. 24.02.1995 ; опубл. 20.12.1997, Бюл. № 34.

8. Пат. № 2065360. Устройство для клеймения ювелирных изделий и инструмента / Г. Г. Угаров, В. Ю. Нейман ; опубл. 1996, Бюл. № 32.

9. Пат. 2062167 РФ, МПК В 21 Ј 7/30. Электродинамический молот / А. И. Стрюк, С. А. Безъязыков, И. А. Шестаков, О. Л. Шелковский ; опубл. 20.06.1996, Бюл. № 7.

10. Шестаков И. Я., Стрюк А. И., Фадеев А. А. Линейные электродинамические двигатели. Конструирование. Практическое использование : монография / Сиб. гос. аэрокосмич. ун.-т. Красноярск, 2011. C. 148 .
11. Фадеев А. А., Шестаков И. Я., Ереско Т. Т. Математическая модель работы ударного устройства на основе линейного электродинамического привода // Решетневские чтения : материалы XVIII Междунар. науч.-практ. конф. (Красноярск, 11-14 нояб. 2014 г.) : в 3 ч. Ч. 1 / под общ. ред. Ю. Ю. Логинова ; Сиб. гос. аэрокосмич. ун-т. Красноярск, 2014. С. 315-316.

12. Пат. 20062168 РФ. МПК В 21 J 7/30. Способ управления работой электродинамического молота / А. И. Стрюк, С. А. Безъязыков, И. А. Шестаков, О. Л. Шелковский ; опубл. 20.06.1996, Бюл. № 17.

13. Ереско С. П., Ереско Т. Т., Фадеев А. А. Совершенствование конструкций и методов проектирования виброударных механизмов : монография / СибГУ им. М. Ф. Решетнева. Красноярск, 2017. 190 с.

14. Швалева Н. А., Фадеев А. А., Ереско Т. Т. Математическая модель работы линейного электродинамического двигателя при ударе с учетом упругой деформации // Решетневские чтения : материалы XXII Междунар. науч.-практ. конф. (Красноярск, 12-16 нояб. 2018 г.) : в 2 ч. Ч. 1 / под общ. ред. Ю. Ю. Логинова ; СибГУ им. М. Ф. Решетнева. Красноярск, 2018. С. 515-516.

15. Киричек А. В., Соловьев Д. Л., Лазуткин А. Г. Технология и оборудование статико-импульсной обработки поверхностным пластическим деформированием. М. : Машиностроение, 2004. 287 с.

16. Дрозд М. С., Матлин М. М., Сидякин Ю. И. Инженерные расчеты упруго-пластической деформации. М. : Машиностроение, 1986. 230 с.

(C) Shvaleva N. A., Fadeev A. A., Eresko T. T., 2019

Shvaleva Natalya Aleksandrovna - master's degree student, Reshetnev Siberian State University of Science and Technology. E-mail: natalyashvaleva@ya.ru.

Fadeev Aleksandr Aleksandrovich - Cand. Sc., docent, Reshetnev Siberian State University of Science and Technology, E-mail: fadeev.77@ mail.ru.

Eresko Tatiana Trofimovna - Dr. Sc., docent, head of Department of Fundamentals of designing machines, Institute of Mechanical Engineering and Mechatronics, Reshetnev Siberian State University of Science and Technology. E-mail: ereskottt@mail.ru.

Швалева Наталья Александровна - магистрант, Сибирский государственный университет науки и технологий имени академика М. Ф. Решетнева. E-mail: natalyashvaleva@ya.ru.

Фадеев Александр Александрович - кандидат технических наук, доцент, заместитель директора; Сибирский государственный университет науки и технологий имени академика М. Ф. Решетнева, Институт машиноведения и мехатроники. E-mail: fadeev.77@mail.ru.

Ереско Татьяна Трофимовна - доктор технических наук, доцент, заведующий кафедрой основ конструирования машин, Сибирский государственный университет науки и технологий имени академика М. Ф. Решетнева. E-mail: ereskottt@ mail.ru. 